\title{
ISOLASI DAN IDENTIFIKASI BAKTERI ENDOFIT DARI TANAMAN PADI (Oryza sativa) SEBAGAI PENGENDALI PENYAKIT HAWAR DAUN BAKTERI AKIBAT Xanthomonas oryzae pv. oryzae
}

\author{
Army Dita Serdani ${ }^{1)}$, Luqman Qurata Aini' ${ }^{2)}$, Abdul Latief Abadi ${ }^{3)}$ \\ 1) Dosen Prodi Agroteknologi, Fakultas Pertanian, Universitas Islam Balitar \\ 2) Dosen Hama Penyakit Tumbuhan, Fakultas Pertanian, Universitas Brawijaya \\ 3) Dosen Hama Penyakit Tumbuhan, Fakultas Pertanian, Universitas Brawijaya
}

\begin{abstract}
Rice cultivation often face obstacles, and one of them is bacterial leaf blight (BLB) disease caused by Xanthomonas oryzae pv. oryzae (Xoo). The application of endophytic bacteria is one of solutions to overcome this problem. Endophytic bacteria are non-pathogenic bacteria, which live in plant tissues. These bacteria could be isolated from the plant tissues. They may adapt to the plant tissues and produce antibiosis that could increase the plant resistance. Therefore, objectives of the research were to isolate the endophytic bacteria from healthy plant tissues and to identify them through morphology, physiology, biochemistry, and molecular. Method of the research was explorative along with three principal activities, such as isolation, selection, and identification on the potential endophytic bacteria. The isolation of the endophytic bacteria from healthy rice tissues has resulted 53 isolates and five of them have antagonistic ability in vitro against Xoo. Isolate ak9 has the highest antagonistic ability, $7.67 \mathrm{~mm}$, in comparison with other isolates. Results of identification showed that those five potential bacteria have close relations, such as da3 with Bacillus cereus, isolate ak9 with Burkholderia sp., isolate ak30 with Enterobacter sp and isolate da9, as well as ak15 are Corynebacterium sp.
\end{abstract}

\section{PENDAHULUAN}

Padi merupakan tanaman pangan utama bagi masyarakat di Indonesia disamping kentang dan jagung dengan produktivitas pada tahun 2004-2008 mencapai 54,6 kuintal/Ha (Dinas Pertanian Jawa Timur, 2009). Namun, budidaya tanaman padi sering mengalami kendala salah satunya adalah penyakit hawar daun bakteri (HDB) akibat Xanthomonas oryzae pv. oryzae (Xoo) dengan gejala pada tanaman ialah tepi daun menguning hingga mengering sehingga disebut sebagai penyakit 'kresek' (Akhtar et al., 2008). Pengendalian berbasis PHT telah dilakukan salah satunya dengan penggunan bakteri endofit.

Bakteri endofit merupakan bakteri yang hidup dalam jaringan tanaman dan tidak bersifat patogenik. Bakteri endofit dapat diisolasi dari jaringan daun, batang, kulit batang, akar dan biji-bijian yang tidak menunjukkan gejala. Menurut Hallman (2001) bakteri endofit berperan sebagai antagonis terhadap patogen, menginduksi ketahanan sistemik dan meningkatkan toleransi tanaman terhadap tekanan lingkungan.

Isolasi merupakan salah satu cara untuk mengetahui agens hayati bermanfaat yang terdapat pada jaringan mapun ekosistem setempat. Identifikasi bakteri endofit terhadap Xoo hanya sebatas pengujian karakter morfologi, sehingga pengujian dengan teknik mikrobiologi 
Army Dita Serdani, Luqman Qurata Aini\&Abdul Latief Abadi. 2016. Isolasi dan Identifikasi

Bakteri Endofit dari Tanaman Padi (Oryza Sativa) sebagai Pengendali Penyakit

Hawar Daun Bakteri Akibat Xanthomonas Oryzae Pv. oryzae

Journal Viabel Pertanian. (2018), 12(1) 18-26

secara molekuler perlu dilakukan. Berdasarkan latar belakang di atas, penelitian dilakukan untuk mengetahui karakter dan potensi bakteri endofit yang diisolasi dari tanaman padi sehat dalam mengendalikan penyakit hawar daun bakteri pada tanaman padi.

\section{METODOLOGI}

Penelitian dilaksanakan mulai bulan Februari sampai dengan Juli 2016 di Laboratorium Ilmu Penyakit Tumbuhan Sublab Bakteriologi Jurusan Hama dan Penyakit Tumbuhan, Fakultas Pertanian Universitas Brawijaya Malang. Pengujian bakteri secara molekuler dilakukan di Laboratorium Mikrobiologi Fakultas Sains dan Teknologi Universitas Islam Negeri Maulana Malik Ibrahim Malang.

\section{Isolasi Bakteri Endofit dan Penyediaan Bakteri Xoo}

Metode isolasi bakteri endofit merupakan hasil modifikasi dari (Phetcharat dan Duangpaeng, 2012 ; Munif et al., 2012). Isolasi dilakukan dengan mengambil tanaman padi sehat diantara tanaman padi sakit. Sementara itu, Bakteri Xoo yang digunakan merupakan isolat koleksi dari Balai Besar Penelitian Tanaman Padi (BBPT Padi) Sukamandi. Isolat tersebut hasil isolasi dari tanaman padi varietas IR64 dan termasuk patotipe IV. Bakteri diremajakan pada media Yeast Extract Dextrose Carbonat YDC.

\section{Seleksi Isolat Bakteri Endofit}

Kandidat bakteri endofit diseleksi pertama kali dengan mengujikan pada tanaman tembakau atau uji hipersensitif (HR). Pengujian ini dilakukan untuk mengetahui bakteri bersifat patogen atau tidak. Kemudiaan dilakukan uji antagonis pada cawan petri dengan memodifikasi metode Nguyen dan Ranamukhaarachchi (2010) yang menggunakan kertas saring dan metode pengabutan (sprayer). Kemampuan antagonis bakteri endofit menghambat Xoo dilakukan dengan menghitung zona hambat yang terbentuk setelah 24-48 jam. Kemudian zona bening bakteri dimasukkan pada media pepton cair $10 \%$ untuk mengetahui jenis antibiosis. Apabila berubah menjadi keruh maka tipe antibiosisnya adalah bakteriostatik. Apabila media tetap jernih maka tipe antibiosisnya adalah bakterisidal (Djatmiko et al., 2007).

\section{Identifikasi Bakteri Endofit}

Identifikasi bakteri dilakukan secara morfologi, fisiologi dan biokimia. Identifikasi bakteri morfologi berdasarkan warna, bentuk, tepi koloni bakteri dan fisiologi dan biokimia dilakukan berdasarkan Buku Bergey's Manual of Determinative Bacteriology (Holt et al., 1994) dan Schaad et al. (2001). Tiga bakteri potensial selanjutnya dilakukan pengujian secara molekuler. Isolasi genom dilakukan berdasarkan protokol Promega kit kemudian dilakukan amplifikasi 16S rRNA dengan Polymerase Chain Reaction (PCR) Data urutan basa nukleotida dianalisis dengan Basic Local Alignment Search Tool (BLAST) (http://www.ncbi.nlm.nih.gov).

\section{Analisis Data}

Analisa data pada penelitian ini dilakukan secara deskriptif kualitatif, yaitu identifikasi. Adapun penjelasannya meliputi morfologi (makroskopis dan mikroskopis) juga biokimia dan molekuler berdasarkan literatur dan software bioinformatika yang mendukung 


\section{HASIL PENELITIAN}

\section{Total Isolat Bakteri Endofit Hasil Isolasi dari Tanaman Padi Sehat}

Hasil isolasi bakteri endofit dari jaringan tanaman padi sehat (akar, batang, dan daun) dengan menggunakan metode pengenceran (Dillution plate) didapatkan 53 isolat (Tabel 1). Jumlah isolat yang didapatkan dari masing-masing jaringan tanaman padi berbeda yaitu akar 32 isolat, daun 12 isolat, dan batang 9 isolat bakteri endofit. Dari hasil tersebut dapat diketahui bahwa bakteri endofit dapat diisolasi dari jaringan tanaman. Hal ini sejalan dengan Tarabily et al. (2003) bahwa bakteri endofit dapat diisolasi dari jaringan tanaman seperti akar, batang, dan daun.

Perbedaan isolat bakteri yang didapatkan dari masing-masing jaringan diduga dipengaruhi oleh tingkat keberadaan bakteri pada jaringan tanaman. Keberadaan bakteri endofit dalam jaringan tanaman dipengaruhi oleh faktor biotik dan abiotik. Faktor biotik yaitu jaringan tanaman, genotip tanaman dan umur tanaman yang digunakan untuk isolasi. Sementara itu, faktor abiotik yang mempengaruhi yaitu faktor lingkungan seperti bahan organik dalam tanah, pemupukan, aplikasi pestisida dan sifat tanah (Munif, 2012).

Tabel 1. Total Isolat Bakteri Endofit yang didapatkan dari Tanaman Padi Sehat

\begin{tabular}{llllll}
\hline & $\begin{array}{l}\text { Bagian } \\
\text { Tanaman }\end{array}$ & $\sum_{\text {Bakteri }}$ Antagonis & $\begin{array}{l}\text { Persentase } \\
\text { Antagonis }\end{array}$ & Bersifat \\
No. & Padi & Endofit & & & \\
\hline 1 & Akar & 32 & 12 & $37,50 \%$ & \\
2 & Batang & 9 & 2 & $22,22 \%$ & \\
3 & Daun & 12 & 3 & $25,00 \%$ & \\
& Total & 53 & 17 & $32,07 \%$ & \\
\hline
\end{tabular}

Tingginya isolat bakteri endofit yang ditemukan pada jaringan akar diduga akar merupakan tempat masuknya unsur hara ke dalam jaringan tanaman. Akar merupakan jaringan tanaman yang berinteraksi dengan tanah dimana tanah merupakan penyedia unsur hara yang dibutuhkan tanaman, bahkan di dalam tanah juga terdapat bakteri yang dapat bersimbiosis dengan tanaman (bakteri endofit). Hal ini sejalan dengan Mihalache (2015) dimana akar merupakan tempat berkolonisasinya bakteri karena merupakan tempat penyedia nutrisi. Selain itu, Prakambang (2007) menyatakan bahwa bakteri endofit dapat berkolonisasi pada lapisan eksodermis dan korteks akar, hal ini disebabkan bakteri mengambil karbon (nutrisi), bahkan bakteri endofit mampu menembus hingga ke dalam xylem.

Bakteri endofit yang bersifat antagonis, sebanyak 17 isolat kemudian diuji hipersensitif, pengujian hipersensitif bertujuan untuk mengetahui apakah bakteri endofit bersifat patogen atau tidak. Dari hasil pengujian hipersensitif (HR) didapatka lima isolat yang menimbulkan nekrosis pada daun tembakau, artinya bakteri tersebut diduga bersifat patogen terhadap tanaman. Selanjutnya, isolat yang tidak bersifat patogen digunakan untuk uji selanjutnya yaitu uji antagonis. Dari hasil uji antagonis pertama didapatkan lima isolat bakteri dengan zona hambat terbesar. 
Army Dita Serdani, Luqman Qurata Aini\&Abdul Latief Abadi. 2016. Isolasi dan Identifikasi Bakteri Endofit dari Tanaman Padi (Oryza Sativa) sebagai Pengendali Penyakit Journal Viabel Pertanian. (2018), 12(1) 18-26

\section{Uji Antagonis Bakteri Endofit terhadap terhadap X. oryzae dalam Cawan Petri (In vitro)}

Lima bakteri endofit dengan nilai zona hambat tertinggi dan dilakukan uji antagonis kembali dengan 6 perlakuan dan 4 ulangan. Pengujian bakteri antagonis terhadap Xoo dilakukan secara in vitro dengan menggunakan metode spray (pengkabutan). Hasil uji antagonis dapat dilihat pada Tabel 2.

Tabel 2. Hasil uji antagonis bakteri endofit terhadap Xoo secara in vitro

\begin{tabular}{ll}
\hline & Indeks penghambatan \\
Perlakuan & \\
\hline P1 (Streptomycin K+) & $30,00 \mathrm{~d}$ \\
P2 (Isolat da9) & $2,75 \mathrm{ab}$ \\
P3 (Isolat da3) & $5,25 \mathrm{bc}$ \\
P4 (Isolat ak9) & $7,47 \mathrm{c}$ \\
P5 (Isolat ak30) & $4,57 \mathrm{abc}$ \\
P6 (Isolat ak15) & $1,67 \mathrm{a}$ \\
\hline
\end{tabular}

Keterangan: da: isolat yang didapatkan dari daun; ak: isolat yang didapatkan dari akar.

- Angka yang diikuti dengan huruf yang sama pada kolom pengamatan menunjukkan hasil yang tidak berbeda nyata pada uji Duncan.

Dari kelima bakteri endofit semua isolat mampu menghambat patogen Xoo namun, indeks penghambatan yang dihasilkan masih lebih kecil dibandingkan dengan kontrol positif. Isolat bakteri ak9 menghasilkan zona bening tertinggi dibandingkan isolat bakteri endofit lainnya. Bakteri ak9 memiliki potensi tinggi dalam menghambat pertumbuhan Xoo jika dibandingkan bakteri endofit lainnya. Kontrol positif dapat menghasilkan zona bening tinggi diduga akibat zat aktif dari bakterisida.

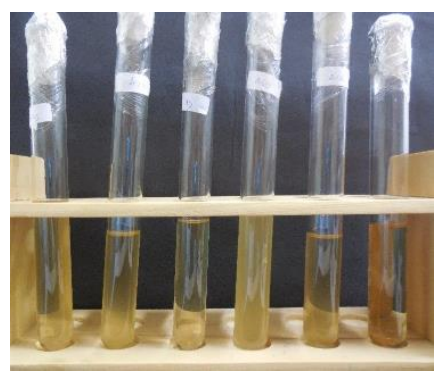

Gambar 1. Tipe Antibiosis pada Pepton Cair 10\%

Zona bening yang terbentuk merupakan bentuk penghambatan bakteri endofit terhadap patogen Xoo. Hal ini akibat bakteri mengeluarkan metabolit sekunder yang dimilikinya. Setiap bakteri memiliki kemampuan yang berbeda dalam mengatasi kondisi lingkungannya, baik terhadap pertumbuhan koloninya maupun dalam menghasilkan metabolit sekundernya (Melliawati et al., 2015). Beberapa mikroba antagonis mampu menghambat pertumbuhan patogen dengan menghasilkan senyawa yang bersifat antibiosis seperti antibiotik, siderofor, dan menghasilkan enzim (Rahman et al., 2013). Dowling dan O'Gara (1994) menyatakan bahwa umumnya senyawa antimikroba maupun siderofor mempunyai peran penting dalam menghambat 
Army Dita Serdani, Luqman Qurata Aini\&Abdul Latief Abadi. 2016. Isolasi dan Identifikasi Bakteri Endofit dari Tanaman Padi (Oryza Sativa) sebagai Pengendali Penyakit

Hawar Daun Bakteri Akibat Xanthomonas Oryzae Pv. oryzae Journal Viabel Pertanian. (2018), 12(1) 18-26

pertumbuhan patogen. Mekanisme penghambatan lainnya yang mampu dilakukan oleh suatu mikroba antagonis adalah dengan adanya kompetisi ruang dan nutrisi, dan parasitisme (Rahmat et al., 2013; Gotz et al., 2006).

Zona bening yang terbentuk diambil dan dimasukkan pada pepton cair $10 \%$ untuk mengetahui tipe antibiosis. Uji tipe antibiosis menunjukkan bahwa kelima bakteri endofit yang digunakan memiliki sifat bakteriostatik (Gambar 1). Hal ini ditandai dengan perubahan warna larutan pepton $10 \%$ setelah digojok selama 24 jam menjadi lebih keruh jika dibandingkan dengan kontrol. Larutan pepton $10 \%$ berubah menjadi keruh diduga bahwa zona bening yang dimasukkan mengaktifkan kembali bakteri patogen Xoo. Sehingga, kelima bakteri endofit yang diujikan hanya memiliki kemampuan menghambat pertumbuhan bakteri patogen Xoo tidak sampai membunuh bakteri tersebut.

\section{Karakterisasi dan Identifikasi Bakteri Endofit \\ Karakterisasi Bakteri Endofit berdasarkan Morfologi}

Karakterisasi morfologi koloni bakteri dilakukan dengan mengamati koloni tunggal dari biakan bakteri. Hasil karakterisasi bakteri endofit yang bersifat antagonis terhadap Xoo secara morfologi dapat dilihat pada Tabel 3. Bakteri endofit yang didapat umumnya memilki bentuk koloni bulat dengan permukaan datar dan cembung, berwarna putih hingga putih keruh dan bertepi rata.

Tabel 3. Karakter Morfologi Bakteri Endofit Hasil Isolasi dari Tanaman Padi Sehat pada Media NA

\begin{tabular}{lllll}
\hline Kode Isolat & \multicolumn{3}{l}{ Morfologi Koloni Bakteri } \\
\cline { 2 - 5 } & Bentuk & Permukaan & Warna & Tepi \\
\hline Isolat da9 & Bulat & Datar & Putih Mengkilat & Rata \\
Isolat da3 & Bulat & Datar & Putih kusam & Bergerigi \\
Isolat ak9 & Bulat & Datar & Putih & Bergerigi \\
Isolat ak30 & Bulat & Cembung & Putih Keruh & Rata \\
Isolat ak15 & Bulat & Cembung & Putih Keruh & Bergerigi \\
\hline
\end{tabular}

Keterangan : da: isolat yang didapatkan dari daun; ak: isolat yang didapatkan dari akar

\section{Karakterisasi Bakteri Endofit berdasarkan Morfologi Fisiologi dan Biokimia}

Hasil uji fisiologi dan biokimia bakteri endofit dapat dilihat pada Tabel 4. Hasil pengujian secara fisiologi dan biokimia menunjukkan bahwa setiap karakter isolat bakteri endofit berbeda-beda. Pada saat uji hipersensitif pada tanaman tembakau semua bakteri endofit tidak menimbulkan bercak pada tanaman tembakau, artinya bakteri endofit bukan merupakan bakteri patogen. Hasil uji Gram menunjukkan bahwa terdapat tiga isolat bakteri endofit termasuk Gram positif. Satu bakteri Gram positif memiliki endospora yaitu isolat da3 dan dua bakteri tidak berendospora (isolat da9 dan ak15). Sementara itu hasil identifikasi isolat ak9 dan ak30 menunjukkan bakteri termasuk Gram negatif. Dari hasil identifikasi bakteri endofit didapatkan bahwa terdapat tiga Genus yang berbeda dari kelima bakteri yaitu Corynebacterium, Burkholderia dan Bacillus serta satu yang termasuk famili Enterobacteriaceae. 
Tabel 4. Karakterisasi Fisiologi dan Biokimia Bakteri Endofit

\begin{tabular}{|c|c|c|c|c|c|}
\hline Karakterisasi & da9 & da3 & Ak9 & Ak30 & Ak15 \\
\hline Uji Hipersensitif & - & - & - & - & - \\
\hline Pengujian Gram & + & + & - & - & + \\
\hline Pengecatan Endospora & - & + & $\mathrm{TU}$ & $\mathrm{TU}$ & - \\
\hline Uji Katalase & + & + & $\mathrm{TU}$ & $\mathrm{TU}$ & + \\
\hline Uji Oksidase & TU & $\mathrm{TU}$ & + & - & TU \\
\hline Oksidatif Fermentatif & TU & TU & - & + & TU \\
\hline $\begin{array}{l}\text { Pigmen Flourescen pada } \\
\text { Media King's B }\end{array}$ & $\mathrm{TU}$ & $\mathrm{TU}$ & - & - & TU \\
\hline $\begin{array}{l}\text { Pertumbuhan pada Media } \\
\text { YDC }\end{array}$ & $\mathrm{TU}$ & TU & - & - & TU \\
\hline Pertumbuhan pada Media $\mathrm{NA}^{+}$ & TU & $\mathrm{TU}$ & - & $\mathrm{TU}$ & TU \\
\hline
\end{tabular}

Keterangan: Karakterisasi fisiologi dan biokimia bakteri endofit (-) : reaksi negatif; (+) : reaksi positif : da9: Corynebacterium, da3: Bacillus, ak9: Burkholderia; ak30: Enterobactericeae, ak15: Corynebacterium

Perbedaan jenis bakteri yang didapatkan diduga bahwa terdapat lebih dari satu macam bakteri yang didapatkan dalam satu jaringan pada satu tanaman. Hal ini sesuai dengan Bhore dan Sathisha (2010) yang menyatakan bahwa pada satu tanaman inang umumnya terdiri atas beberapa genus dan spesies bakteri endofit. Penggunaan bakteri Genus Baciilus, Corynebacterium, Burkholderia dan famili Enterobacteriaceae sebagai agens hayati telah banyak digunakan. Menurut Patihong (2012) Corynebacterium dapat menekan serangan yang ditimbulkan oleh penyakit hawar daun bakteri oleh patogen Xoo. Genus Bacillus telah banyak digunakan sebagai agens hayati. Monteiro et al. (2005) melaporkan bahwa B. subtilis mampu menekan patogen $X$. campestris dan $X$. oryzae. Burkholderia cepacia dapat menurunkan serangan jamur Fusarium moniliforme pada tanaman tebu (Mendes et al., 2007).Sementara itu Naureen et al. (2005) menyatakan bahwa Enterobacter dapat bersifat antagonis terhadap pathogen.

\section{Identifikasi Molekuler}

Hasil sekuensing DNA dianalisis dengan program Bioedit. Dari setiap sampel diperoleh dua sekuen, hasil sekuensing menggunakan primer forward dan primer reverse. Kedua sekuen diedit sesuai dengan kromatogram. Sekuen yang telah sesuai dengan kromatogram selanjutnya dilakukan penjajaran berpasangan (pairwise alignment) agar dapat diperoleh sekuen konsesus yang selanjutya diedit lagi sehinga akhirnya diperoleh sekuen tunggal yang meruapakan sekuen dari gen $16 \mathrm{~S}$ rDNA.

Hasil analisis dengan menggunakan BLAST menunjukkan bahwa semua isolat memiliki homologi 99\% dengan sekuen bakteri pada database. Isolat da3 memiliki homologi 99\% dengan Bacillus cereus strain F2-1-21 dengan nomor akses (KX350008.1), sementara itu isolat ak9 memiliki homologi dengan Burkholderia sp. DOP-Ma3 dengan no akses (KT 993571.1). Isolat ak30 memiliki homologi dengan Enterobacter sp. DRSBII 10 dengan nomor 
Army Dita Serdani, Luqman Qurata Aini\&Abdul Latief Abadi. 2016. Isolasi dan Identifikasi

Bakteri Endofit dari Tanaman Padi (Oryza Sativa) sebagai Pengendali Penyakit

Hawar Daun Bakteri Akibat Xanthomonas Oryzae Pv. oryzae

Journal Viabel Pertanian. (2018), 12(1) 18-26

akses (JF 514550.1). Query coverage menunjukkan presentase basa dari sekuen strain yang diuji yang cocok dengan strain homolognya. Semua isolat yaitu da3 dan ak9 memiliki nilai coverage $100 \%$ (Tabel 5), artinya semua basa nukleotida dari sekuen kedua strain tersebut seluruhnya bisa cocok dengan bakteri homolognya. Namun isolat ak30 hanya memiliki nilai coverage $93 \%$.

Tabel 5. Hasil Analisis Sekuen dengan BLAST

\begin{tabular}{lllllll}
\hline Isolat & $\begin{array}{l}\text { Query } \\
\text { ID }\end{array}$ & Hasil BLAST & $\begin{array}{l}\text { Max } \\
\text { score }\end{array}$ & $\begin{array}{l}\text { Query } \\
\text { coverage }\end{array}$ & $\begin{array}{l}\text { E } \\
\text { value }\end{array}$ & $\begin{array}{l}\text { Max } \\
\text { identif } \\
\text { y }\end{array}$ \\
\hline da3 & $\begin{array}{l}\text { lc1|176 } \\
531\end{array}$ & $\begin{array}{l}\text { Bacillus cereus strain F2-1- } \\
\text { 21 } 2551\end{array}$ & $100 \%$ & 0 & $99 \%$ \\
ak9 & $\begin{array}{l}\text { lc1|467 } \\
\text { Burkholderia sp. DOP-Ma3 }\end{array}$ & 2542 & $100 \%$ & 0 & $99 \%$ \\
ak30 & $\begin{array}{l}\text { (KT 993571.1) } \\
\text { lcl|124 } \\
997\end{array}$ & $\begin{array}{l}\text { Enterobacter } \text { sp. DRSBII 10 } \\
\text { (JF 514550.1) }\end{array}$ & 2582 & $99 \%$ & 0 & $99 \%$ \\
\hline
\end{tabular}

Skor maksimum (Maximum score) menunjukkan ukuran perbedaan statistik dari alignment. Skor tinggi menunjukkan kedua sekuen semakin mirip. Isolat ak30 memiliki skor tertinggi yaitu 2582 sedangkan ak9 memiliki skor terendah yaitu 2542. Nilai Expectation value (E-value) yang rendah menunjukkan kedua sekuen semakin mirip. Nilai ekspektasi dari semua isolat nol, artinya setiap isolat uji memiliki kemiripan yang tinggi dengan sekuen homolognya. Sekuen bakteri dari 16s rDNA dianalisis filogenetik untuk mengetahui hubungan kekerabatan isolat bakteri yang diteliti dengan spesies lainnya.

Dari gambar filogenetik (Gambar 2), dapat dilihat bahwa grup isolat da3, ak9 dan ak30 terkumpul pada grup tersendiri dengan nilai bootstrap tertinggi yaitu 100. Nilai boostrap yang tinggi menunjukkan bahwa stabilitas hasil yang digunaan dalam penjajaran alignment artinya data semakin baku. Ak9, da3 dan ak30 membentuk kelompok monofiletik yaitu sebuah takson yang mengandung spesies yang semuanya berasal dari nenek moyang tunggal yang sama (Holmes, 2003). Sementara itu ak30 memiliki boostrap dengan Pseudomonas fluoresens dengan nilai boostrap 92, artinya keduanya berada dalam satu kelompok yang kuat. Sementara itu, Esherichia coli berbeda dengan lainnya sebagai outgroup, hal ini diduga E. Coli tidak memiliki kemiripan dengan ketiga bakteri yang diuji yaitu (da3, ak9, dan ak30).

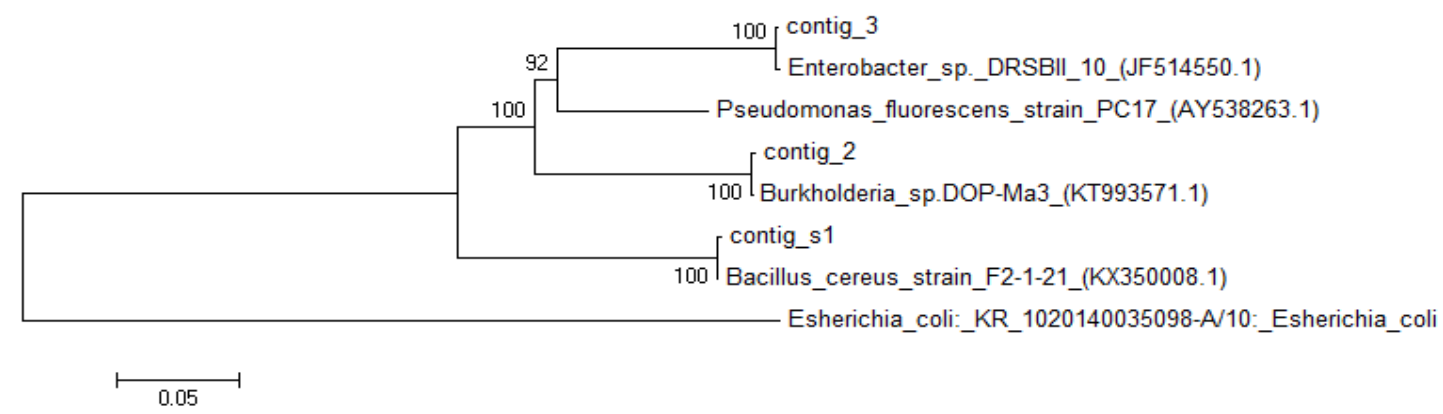

Keterangan contig 1: isolat da3; contig 2: isolat ak9; contig 3:ak30

Gambar 2. Pohon Filogenetik 
Bacillus cereus yang diisolasi dari lahan yang terkena Xanthomonas campestris mampu menekan penyakit tersebut hingga mencapai $71 \%$ (Assis, 1997). Bakteri ini mampu berkolonisasi dengan rizosfer tanaman sehingga dapat memacu pertumbuhan tanaman. Salah satu aktivitas yang dilakukan ialah mampu melakukan pembentukan siderofor (Chakraborty et al., 2006). Sementara itu, bakteri Burkholderia cepacia dapat diisolasi dari benih padi (Hongriitipun et al., 2014) dan bakteri golongan Enterobacter sp. antagonis terhadap Rhizoctonia solani (Velusamy dan Kim, 2011).

\section{Kesimpulan}

1. Isolasi bakteri endofit dari jaringan tanaman padi sehat akar, batang dan daun didapatkan 53 isolat dan sebanyak lima isolat bakteri endofit potensial dalam menekan populasi Xoo. Bakteri endofit dari jaringan akar merupakan yang paling banyak ditemukan dengan persentase yang bersifat antagonis sebesar $37,50 \%$.

2. Terdapat tiga bakteri berpotensi secara in vitro dan in vivo yaitu Bacillus cereus isolat da3, Burkholderia sp. isolat ak9, dan Enterobacter sp. isolat ak30. Secara in vitro dapat menekan patogen Xoo berturut-turut yaitu 5,25 mm; 7,47 mm; dan 4,57 mm.

\section{DAFTAR PUSTAKA}

Akhtar, M., Abdul R., and Abdul H. 2008. Comparison of Methods of Inoculation of Xanthomonas oryzae pv.oryzae in Rice Cultivars. Pak. J. Bot. 40 (5): 2171-2175.

Bhore SJ, Sathisha G. 2010. Screening of Endophytic Colonizing Bacteria for Cytokinin-Like Compounds: Crude Cell-Free Broth of Endophytic Colonizing Bacteria is Unsuitable in Cucumber Cotyledon Bioassay. World J. Agric. Sci. 6 (4): 345-352.

Chakraborty U., Chakraborty B., and Basnet M. 2006. Plant Growth Promotion and Induction of Resistance in Camellia sinensis by Bacillus megaterium. J Basic Microbiol. 46:186195.

Chanway, C. 1999. Bacterial Endophytes; Ecological and Practical Implications. Department of Forest Sciences, Vancouver, Canada.

Hallman, J. 2001. Plant Interaction with Endophytic Bacteria. Institut for Plant Disease University of Bonn Nuballe 9, 53115 Bonn. Germany.

Holt, J.G., Krieg, N.R., Sneath, P.H.A., Staley, J.T. Williams, S.T. 1994. Bergey's Manual of Determinative Bacteriology. $9^{\text {th }}$ ed. Maryland, USA: Williams and Wilkins.

Mendes, R., Pizzirani K., Araujo W., Raaijmakers. 2007. Diversity of Cultivated Endophytic Bacteria from Sugarcane: Genetic and Biochemical Characterization of Burkholderia cepacia complex isolates. Appl Environ Microbiol 73: 7259-7267.

Munif, A., Suryo Wiyono dan Suwarno. 2012. Isolasi Bakteri Endofit Asal Padi Gogo dan Potensinya sebagai Agens Biokontrol dan Pemacu Pertumbuhan. J. Fitopatol. Indonesia. 8 (3): 57-64. 
Army Dita Serdani, Luqman Qurata Aini\&Abdul Latief Abadi. 2016. Isolasi dan Identifikasi

Bakteri Endofit dari Tanaman Padi (Oryza Sativa) sebagai Pengendali Penyakit

Hawar Daun Bakteri Akibat Xanthomonas Oryzae Pv. oryzae Journal Viabel Pertanian. (2018), 12(1) 18-26

Montealegre, J.R., R. Reyes L.M. Perez R. Herrera P., and Besoain. 2003. Selection of bioantagonistic bacteria to be used in biological control of Rhizoctonia solani in tomato. Electronic J. Biotechnol. 6:116-127.

Naureen, Z., S. Yasmin, S. Hameed, K.A. Malik and F.Y. Hafeez. 2005. Characterization and Screening of Plant Growth Promoting Bacteria Isolated from Maize Grown in Pakistani and Indonesian Soil. J. Basic Microbiol. 45: 447-459.

Nguyen, M.T dan Ranamukhaarachchi, S.L. 2010. Soil Borne Antagonist For Biological Control Of Bacterial Wilt Caused By Ralstonia solanacearum In Tomato and Pepper. J. Plant Pathology. 92(2): 395-406.

Patihong, R. 2012. Uji Efektivitas Bakteri Antagonis Corynebacterium untuk Mengendalikan Kresek (Xanthomonas campestris pv. oryzae) pada Tanaman Padi MT. 2012. Instalasi Pengamatan Peramalan \& Pengendalian OPT (IP3OPT) Wilayah V Pinrang Dinas Pertanian Tanaman Pangan dan Hortikultura. UPTD.Balai Proteksi Tanaman Pangan Dan Hortikultura Propinsi Sulawesi Selatan.

Phetcharat, P. and Duangpaeng A. 2012. Screening of Endophytic Bacteria from Organic Rice Tissue for Indole Acetic Acid Production. Elsevier. Procedia Engineering. 32: 177-183.

Prakambang, J. 2007. Microbial Communities and Their Gene Expression in Rice Endophytic Diazotroph Bacteria. A Thesis Submitted in Partial Fulfillment of the Requirements for the Degree of Master of Science in Biotechnology Suranaree University of Technology. Thailand.

Schaad, N.W., J.B. Jones, and W. Chun. 2001. Plant Pathogenic Bacteria. 3rd Edition. The American Phytopathological Society. U.S.A. Hal 165.

Tarabily, K., Nassar A.H., and Sivasithamparam K. 2003. Promotion of Plant Growth By An Auxin-Producing Isolate of The Yeast Williopsis Saturnus Endophytic in Mayze Roots. The Sixth UAE University Research Conference: 60-69.

Widiyanti, A., Maya S., dan Nengah D. K. 2011. Isolasi dan Karakterisasi Bakteri Resisten

Merkuri di Hilir Kali Mas Surabaya. Jurusan Biologi, Fakultas Matematika dan Ilmu Pengetahuan Alam Institut Teknologi Sepuluh Nopember: Surabaya. 